\title{
RISK ALLOCATION OF INTERFACES BETWEEN CONSTRUCTION AND CORE SYSTEM CONTRACTS : A CASE STUDY ON TAIWAN HIGH SPEED RAILROAD PROJECT
}

\author{
Tsai, Tsung-Chieh \\ Department of Construction Engineering \\ National Yunlin University of Science \\ \&Technology,Taiwan \\ 123, University Road, Section 3, Douliu,Yunlin, Taiwan 640 \\ tctsai@ce.yuntech.edu.tw
}

\author{
Yen, Chia-Cheng \\ Shinkansen Construction R4 Office \\ Mitsubishi Heavy Industries, Ltd.,Taiwan \\ 488, Yen-Ping St. Chia-yi City Taiwan 600 \\ jason.yen0418@msa.hinet.net
}

\begin{abstract}
Normally, the owner must contract with construction contractors and core system contractor at the same time in the public projects. Especially, for an infrastructure project, the core system contractor and construction contractor may sometimes pass their requests concerning with ambiguous conditions of interfaces to the owner by changing the design, or by modifying the works. In spite of reasonable or unreasonable requests, this situation always mutually causes both parties to face unexpected happenings and to suffer unknown risks. Also, for the both parties, it is not likely to exactly estimate the extra cost and time brought by the interface risks. Nevertheless, there are lots of problems concerning with the risk allocation in the engineering interfaces between construction and core system contracts, but not any contract relationship between both of these parties. This study tried to identify risk factors of interface between construction and core system contractors by comparing the contract conditions in the FIDIC, AIA, NEC, and ENAA etc. Taiwan High Speed Railroad Project was used as a case study by questionnaire to examine the differences between the findings of the above mention and realities of the project execution.
\end{abstract}

\section{Keywords: Risk Allocation, Contract Comparison, THSRP, Construction Contract, Core System Contract}

\section{INTRODUCTION}

\subsection{Background}

The public projects are normally involved with long-term contracts, and many interface concerns or risks are inherent with the planning, design, construction and handover phases. In order to reduce project risks, the owner would transfer all the uncertainties and liabilities to the contractors through contract clauses. However, to complete a complicate project, the owner must contract with different kinds of specialist contractors. Normally, there are at least two main contractors, construction contractor and core system contractor, need to be contracted with at the same time. Due to the natures of project uncertainties and unknown events, the issues related to unfair distribution of project risks by unfair or unreasonable contracts between the contracted parties become unavoidable. Especially, for an infrastructure project, the core system contractor and construction contractor may sometimes pass their requests concerning with ambiguous conditions of interfaces to the owner by changing the design, or by modifying the works. In spite of reasonable or unreasonable requests, this situation always mutually causes both parties to face unexpected happenings and to suffer unknown risks. Also, for the both parties, it is not likely to exactly estimate the extra cost and time brought by the interface risks. Moreover, it is possible to make the damages of product quality and delay the whole project.

Taiwan High Speed Railroad Project (THSRP) is the largest BOT project in the world, involves with the works of civil works, trackwork, core system, stations, depots etc..
To complete these works, the owner must contract with different specialist contractors at the same time. To cite a real problem happened in "the Ascending Machine Pit \& Turn Table of Train" of the foundation in the depot. Due to the repeatedly change the design of core system cause the size, shape, dimensions, level, direction etc. of foundation construction need to be modified. The following is to rework the foundation formwork, rebars, piping and embedment. Also, the waiting time led to the idling of the processes in next step. Besides, this situation increased the cost of design change and made the schedule lost control. The contractors face unexpected happenings and to suffer unknown risks. Nevertheless, there are lots of problems concerning with the risk allocation in the engineering interfaces between construction and core system contracts cause the disputes in the project. But, as shown in Figure 1, there is not any contract relationship between construction contractor and core system contractor. Lots of unfair and unreasonable phenomenon is originated from these ambiguous relationships among the owner, construction contractor and core system contractor.

\subsection{Purpose of this paper}

The contract comparing, risk factor collection, questionnaire was used to probe into the problem in the case study of THSRP. And there are two main purposes in this study. The first one tried to identify interface risk factors between construction and core system contractors. The second one used the comparison of contract clauses which concerned with the risk factors in the FIDIC, AIA, NEC, and ENAA to examine with the contract clauses of 
THSRP. The results are useful to participant of project when evaluate the importance of various factors in interface risk, and make the risk allocation more fair and reasonable during making the contract.

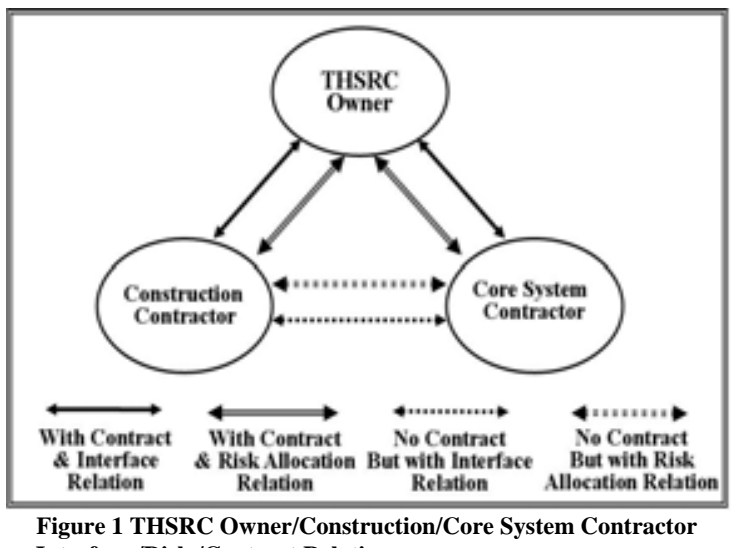

Interface /Risk /Contract Relation

\section{THE PRINCIPLE OF CONTRACT RISK ALLOCATION}

2.1 The Purpose of Contract Risk Allocation

To keep the best efficiency and benefits in the engineering contract not only shift all the risk to the other participant. Normally in the contract, one party may shift most of risks to other party who are bearing too much cost of the risk. So the quotation of prices is needed to rise up to balance the cost. The result is increasing the owner cost which may make budget over. Contrarily, the extreme case is the owner bearing all risks and pay for all damaged loss. But this way was not adopt suitable risk allocation, also let the engineering contract with low efficiency and benefits. Therefore to promote the efficiency and balanced benefits of both parties, the contract must take suitable risk allocation (Ku, 2004).

So, the main purposes of risk allocation in contract are,

(1) To share unavoidable risks by participants of project.

(2) To eliminate unnecessary risks for participants.

(3) To reduce the fixed cost of the risk.

\subsection{The Principle of Risk Allocation}

(1)The Principle of Risk Allocation in Taiwan civil law

The civil law in Taiwan only legislates in the section of contract article 508 to describe about the risk allocation of the engineering contract. It defines the principle of risk allocation between the owner and contractor. But this principle only concerns the timing of risk allocation in the provisional acceptance of owner. Before the acceptance of owner, all of work damaged and loss risk during the construction period is belong to contractor. It means before the project is taken over by owner, contractor should bear any damaged or loss duty whether the responsibility belongs to contractor or not.

(2)Risk Allocation by Contract Clauses
Figure 2 is quoted from the study of Ming-Teh Wang (2003), risk allocation by contract clauses includes seven kinds of conditions.

1). Definitely stipulate that the owner should take certain risks.

2). Definitely stipulate that the contractor should take certain risks, and the contractor have no objection to such allocation.

3). Definitely stipulate that the contractor should take certain risks, but the contractor is unwilling to accept such allocation, transgressing the principle of good faith and fair dealing.

4). Some sketchy stipulations about certain risks and for this reason the risk allocation remains unconfirmed.

5). Two contracting parties have consensus that the owner should take the risks.

6). Two contracting parties have consensus that the contractor should take the risks.

7). Two contracting parties have no consensus as to risk responsibilities.

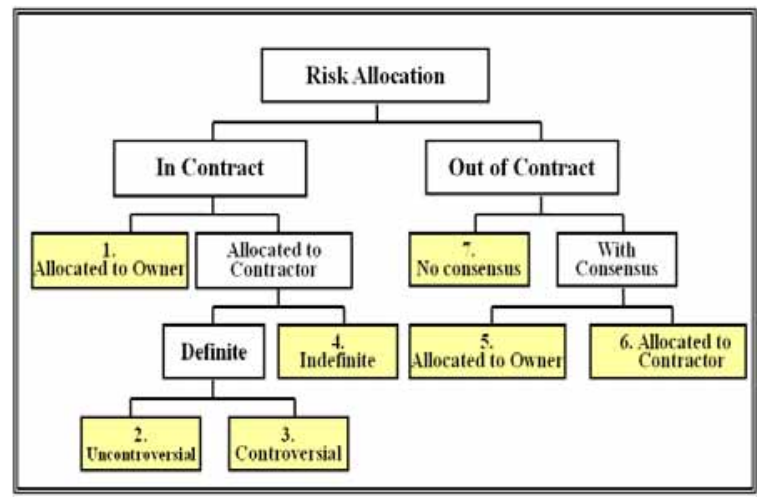

Figure 2 Risk Allocation by contract clauses (Wang 2003)

\section{THE INTERFACE RISK BETWEEN CONTRACTORS}

After the brainstorming and interview with practitioners and senior engineers, this study classified the interface risks into seven categories as bellows. These are (A)Variation; (B) Care of works; (C) Force Majeure; (D) Cooperation \& Coordination; (E) Chang in Laws; (F) Contractor's Liability; (G) Suspension and Termination.

To identify significant risks in interfaces between construction and core system contractors in THSRP, a questionnaire survey was undertaken. The questionnaires were designed to ask respondents to rate the relative influence for the interface risk of the seven risk categories. Except "Force Majeure" and "Chang in Laws", the remaining five risk categories were also designed to ask the owner, construction contractors and core system contractors. Sixty questionnaires were sent to the participants of THSRP and thirty-eight effective samples were received. The respondents included owner's representative, managers, senior site Engineers and the supervisor of the contractors.

In order to rank each factors for seven risk categories, the total score was calculated. The total score of each risk 
factor is the multiplication of the response percentage for each relative influence and assigned weight factor (Absolutely no influence $=0$, no influence $=1$, a little no influence $=3$, a little influence $=5$, influence $=7$, Very Highly influence=9). The $A \sim G$ categories and results of the survey were as shown in Tables 1.

Table 1 Rank and Total Score of A G interface Risk Factors

\begin{tabular}{|c|c|c|}
\hline Rank & A. Variation Risk Factor & Total Score \\
\hline 1 & $\begin{array}{l}\text { A07-Change or add in the plant \& equipment } \\
\text { (equipment ,material, tests) }\end{array}$ & 290 \\
\hline 2 & A03-Change the level ,location, \& size of the structure & 272 \\
\hline 3 & A04-Change the working sequence ,timing, procedures & 261 \\
\hline 4 & A02-Change the quality and characteristic in the contract & 255 \\
\hline 5 & A05-Change the working location and working scope & 249 \\
\hline 6 & A01-Change the Bill of quantities in the contract & 238 \\
\hline 7 & A06-Delete some kinds of the works & 233 \\
\hline Rank & B. Care of works Risk Factor & Total Score \\
\hline 1 & B01-Design Drawing not so clearly & 284 \\
\hline 2 & B05-Delay in Instruction Variation & 276 \\
\hline 3 & B02-Jobsite can not fellow the design and specification & 269 \\
\hline 4 & B03-Lack of the supervision and manage ability & 259 \\
\hline 5 & B07-Lack of the engineering experience & 245 \\
\hline 6 & B06-Unreasonable request in the jobsite & 229 \\
\hline 7 & B08-Loss \& damage of the structure or plant & 210 \\
\hline 8 & B04-Financial difficulty & 164 \\
\hline Rank & C. Force Majeure Risk Factor & Total Score \\
\hline 1 & C01-Natural disaster (Typhoon, earthquake, flood) & 274 \\
\hline 2 & $\begin{array}{l}\text { C04- Riot, or disorder otherwise than among } \\
\text { employees of the Contractor }\end{array}$ & 248 \\
\hline 3 & C05-Inhabitant resist & 230 \\
\hline 4 & C03-Civil war, rebellion, revolution, insurrection & 205 \\
\hline 5 & $\begin{array}{l}\text { C02-war, invasion, act of foreign enemies Civil war, } \\
\text { rebellion, revolution, insurrection }\end{array}$ & 200 \\
\hline Rank & D. Cooperation \& Coordination Risk Factor & Total Score \\
\hline 1 & D04-Benefits conflict & 285 \\
\hline 2 & D01-Low interface Coordination planning & 270 \\
\hline 3 & D05-High cost in coordination & 267 \\
\hline 4 & D06-Tie in Government policy & 256 \\
\hline 5 & D02-Low will of interface coordination & 242 \\
\hline 6 & D03-Incompetent interface coordinator & 240 \\
\hline Rank & E. Chang in Laws Risk Factor & Total Score \\
\hline 1 & E04-Over restrictions on the law & 268 \\
\hline 2 & E01-New legislation & 246 \\
\hline 3 & E02-Abolish the original law & 240 \\
\hline 4 & E03-New define of the old law & 228 \\
\hline Rank & F. Contractor's Liability Risk Factor & Total Score \\
\hline 1 & F01-Schedule Delay of Contractor & 278 \\
\hline 2 & F03-Not improve the defect & 271 \\
\hline 3 & F04-Not fulfil the contract & 269 \\
\hline 4 & F02-The guarantee of contractor & 248 \\
\hline 5 & F05-Site not cleaning & 236 \\
\hline Rank & G. Suspension \& Termination Risk Factor & Total Score \\
\hline 1 & $\begin{array}{l}\text { G04-Suspension due to the contractor's bad design , } \\
\text { Low technique and imperfect material }\end{array}$ & 276 \\
\hline 2 & G02-Suspension due to the contractor's violation & 271 \\
\hline 3 & G06-Termination due to the continue suspension & 258 \\
\hline 4 & G03-Suspension due to the owner's convenience & 244 \\
\hline 5 & G01-Suspension due to the owner's fault & 239 \\
\hline 6 & G05-Termination due to the owner's convenience & 202 \\
\hline
\end{tabular}

\subsection{Interface Risk Analysis}

As shown in Table 1, there are four risk factors in A category found to be significant. These four risk factors of A07, A03, A04 and A02 may generalize as "Change the quality and characteristic of work". "Change or add in the plant \& equipment (including equipment, material, tests)” was ranked as the top item in the list. There are four risk factors in B category found to be significant. These there risk factors of B01, B05, B03 and B02 may generalize as "Change the design of work". "Design drawing not so clearly” was ranked as the top item in this category. But four of them are almost the same significance in this ranking. There is one risk factor in $\mathrm{C}$ category found to be significant. It is C01"Natural disaster (Typhoon, earthquake, flood)". There are four risk factors in D category found to be significant. These there risk factors of D04, D01, D05 and D06 may generalize as "Conflict in coordination of interface". "Benefits conflict" was ranked as the top item in this category. There is one risk factor in $\mathrm{E}$ category found to be significant. It is E04 "Over restrictions on the law”, which is including the Labor Safety and Health Law, Environmental Health and Safety Law, Architecture Law and Fire Fighting Law. There are three risk factors in F category found to be significant. These there risk factors of F01, F03 and F04 may generalize as "Defect in execution of contract". The "Schedule Delay of Contractor" was ranked as the top item in this category. There are three risk factors in G category found to be significant. "Suspension due to the contractor's bad design, Low technique and imperfect material" was ranked as the top item in this category. The all results conform to the general concern for interface risk between construction and core system contractors in THSRP.

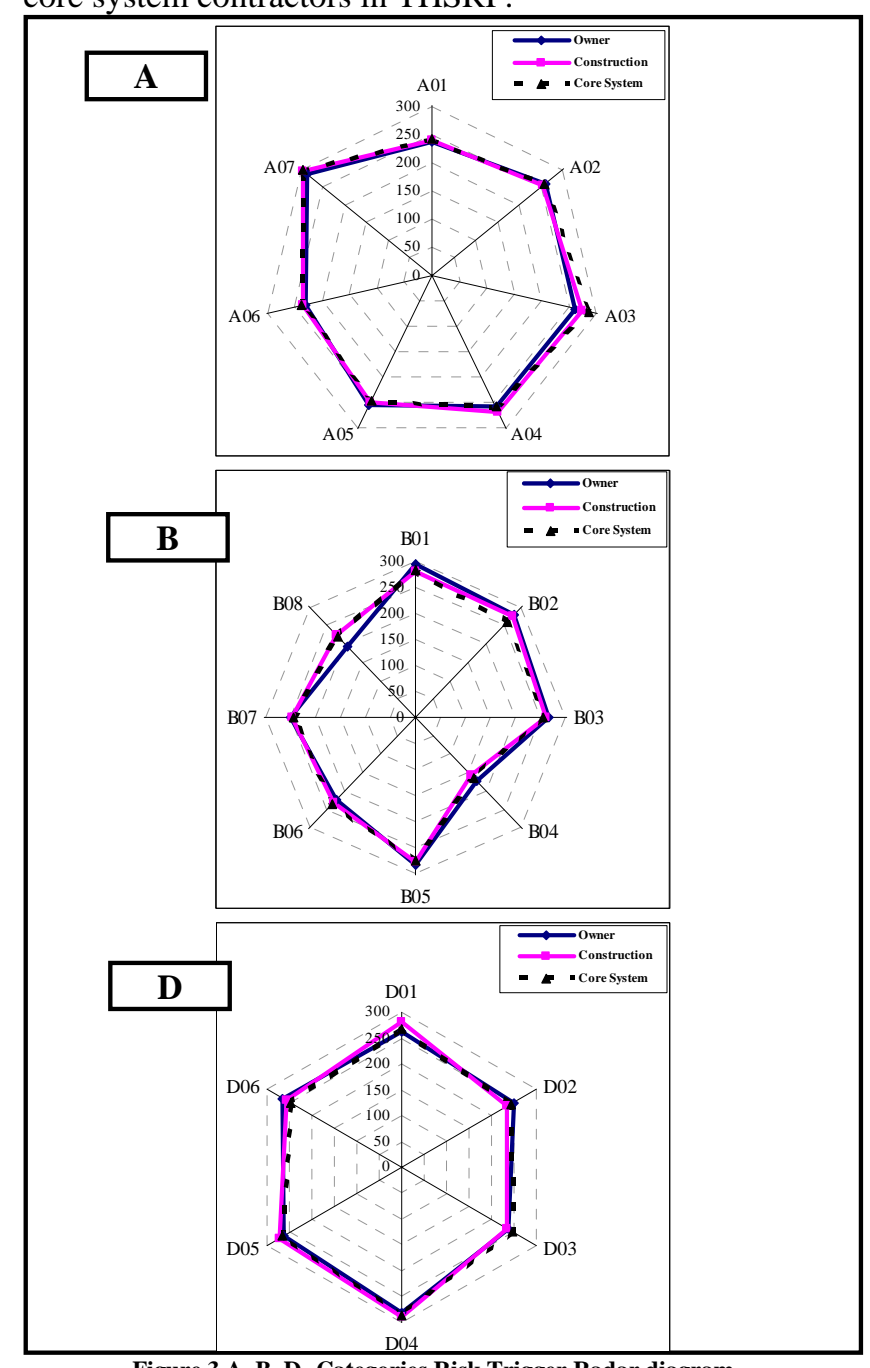

Figure 3 A, B, D, Categories Risk Trigger Radar diagram 


\subsection{Risk Trigger distribution analysis}

As shown in Figure 3, the top three risk categories of "Variation Risk", "Care of Works Risk" and "Cooperation \& Coordination Risk" were deemed as the risk triggers by owner, construction contractor and core system contractor. In Figure 3, Part A in the "Variation Risk" category, because the construction and core system Contractors request the "variation of change or add in the plant \& equipment" to the owner frequently, the occurrence rate was high. "Change the level, location, \& size of the structure" was normally requested by core system contractor with the high rate. "Change the working sequence, timing, procedures" was normally requested by construction contractor with the high rate. Part B, in the "Care of Works Risk" category, owner and core system contractor were the common risk trigger of "the Design Drawing not so clearly" with high rate. "Delay in Instruction Variation” was normally originated from owner with high rate. Part D, in the "Cooperation \& Coordination Risk" category, the construction contractor was the main risk trigger lead to "Low interface Coordination planning" with high rate.

\begin{tabular}{|c|c|}
\hline $\begin{array}{l}\text { Contract } \\
\text { Type }\end{array}$ & $\begin{array}{c}\text { Relation clause } \\
\text { Variation \& adjustment }\end{array}$ \\
\hline $\begin{array}{l}\text { FIDIC } \\
(1995)\end{array}$ & $\begin{array}{l}\text { 14.1Variations may be initiated by the Employer at any time prior to } \\
\text { issuing the Taking-Over Certificate for the Works, by an instruction } \\
\text { for the Contractor to submit a proposal. They shall not make any } \\
\text { alteration or modification of the Permanent Works, unless the } \\
\text { Employer instructs or approves a Variation. }\end{array}$ \\
\hline $\begin{array}{l}\text { NEC/ECC } \\
(1995)\end{array}$ & $\begin{array}{l}60.1 \text { Variation to the work are made by a Project Manager's } \\
\text { instruction to change the work information. A variation may } \\
\text { comprise deletion or addition of work or alteration to work. It may } \\
\text { include changes to the employer's design, to design criteria or to } \\
\text { performance requirements for the contractor's design. }\end{array}$ \\
\hline $\begin{array}{c}\text { AIA/A201 } \\
\text { (1997) }\end{array}$ & $\begin{array}{l}\text { 7.3.1 A Construction Change Directive is signed by the Owner and } \\
\text { Architect, directing a change in the Work prior to agreement on } \\
\text { adjustment, if any, in the Contract Sum or Contract Time, or both. } \\
\text { The Owner may by Construction Change Directive, without } \\
\text { invalidating the Contract, order changes in the Work within the } \\
\text { general scope of the Contract consisting of additions, deletions or } \\
\text { other revisions, the Contract Sum and Contract Time being adjusted } \\
\text { accordingly. }\end{array}$ \\
\hline $\begin{array}{l}\text { ENAA } \\
(1996)\end{array}$ & $\begin{array}{l}\text { 39.2.1 If the Employer proposes a Change , it shall require the } \\
\text { Contractor to prepare and furnish to the Project Manager as soon as } \\
\text { reasonably practicable a "Change Proposal," which shall include the } \\
\text { following: 1.brief description of the Change. 2. effect on the Time } \\
\text { for Completion Manager. 3. estimated cost of the Change. } 4 . \text { effect } \\
\text { on Functional Guarantees, if any, and. 5.effect on any other } \\
\text { provisions of the Contract }\end{array}$ \\
\hline $\begin{array}{c}\text { THSRC } \\
\text { Construction } \\
\text { (2000) }\end{array}$ & $\begin{array}{l}\text { The Employer may order for any reason to achieve satisfactory or } \\
\text { timely completion. Such variations may include: Additions, } \\
\text { omissions, substitutions, alterations, changes in alignment, quality, } \\
\text { form, character, kind, position, dimension, level or line etc. Any } \\
\text { increase in the Contract Price or extension of time pursuant to } \\
\text { Contract for complying with an instruction from the Employer. }\end{array}$ \\
\hline $\begin{array}{c}\text { THSRC } \\
\text { Core System } \\
(\mathbf{2 0 0 0 )}\end{array}$ & $\begin{array}{l}\text { The Employer shall notify the Installation Contractor if he proposes } \\
\text { to instruct a variation, the Contractor considers instructed variation } \\
\text { will prevent from materially conforming with the Base Design } \\
\text { Criteria, and which is relevant to the Core System Design. If the } \\
\text { Employer changes the design of the construction such that the } \\
\text { Construction Design does not conform to the Base Design Criteria, } \\
\text { to the extent that the Base Design Criteria is relevant to the Core } \\
\text { System Design. Which gives rise to an incompatibility between the } \\
\text { Core System Design and the construction design the Contractor } \\
\text { incurs additional costs or is delayed in its performance, the } \\
\text { Contractor shall be entitled to claim an increase in the Contract } \\
\text { Price or an Extension of Time. }\end{array}$ \\
\hline
\end{tabular}

\section{COMPARSION OF CONTRACT CONDITIONS}

As shown in Figure 3, the contract clauses concern with the top three risk categories of "Variation Risk", "Care of Works Risk" and "Cooperation \& Coordination Risk" in the General Condition of FIDIC $19951^{\text {st }}$ Edition, NEC/ECC $19952^{\text {nd }}$ Edition, AIA Document A201 1997 Edition, ENAA 1996 Edition and standard forms of THSRP contract were compared in Table 2 5. Through this comparison, the reasonable risk allocation in contract clause can be analyzed and found.

Table3 Contract comparison of Care of Works Risk allocate to the Owner

\begin{tabular}{c|l}
\hline $\begin{array}{c}\text { Contract } \\
\text { Type }\end{array}$ & \multicolumn{1}{c}{ Care of Works } \\
\cline { 2 - 2 } $\begin{array}{c}\text { FIDIC } \\
\text { (1995) }\end{array}$ & $\begin{array}{l}\text { Risk allocate to Owner } \\
\text { Employer. If a Taking-Over Certificate is issued for any Section of } \\
\text { the Works, responsibility for the care of the Section shall then pass to } \\
\text { the Employer. }\end{array}$ \\
\hline $\begin{array}{c}\text { NEC/ECC } \\
\text { (1995) }\end{array}$ & $\begin{array}{l}\text { Loss of or damage to the parts of the works taken over by the } \\
\text { employer, except loss or damage occurring before the issue of the } \\
\text { defects certificate which is due to 1. a defect which existed at take } \\
\text { over, 2. an event occurring before take over which was not itself an } \\
\text { employer's risk or 3. the activities of the contractor on the site after } \\
\text { take over. }\end{array}$ \\
\hline $\begin{array}{c}\text { AIA/A201 } \\
\text { (1997) }\end{array}$ & $\begin{array}{l}\text { 35. If, during the execution of the Contract, the Contractor shall } \\
\text { encounter on the Site any Unforeseen Conditions belong to } \\
\text { Employer's Risk. }\end{array}$ \\
\hline $\begin{array}{c}\text { (1996) } \\
\text { THSRC }\end{array}$ & $\begin{array}{l}\text { 1. Excepted Risks and Force Majeure belong to the Owner. } \\
\text { 2. If the Owner issues a Certificate of Completion for any Section of } \\
\text { the Works, the Contractor shall cease to be responsible for the care } \\
\text { of that Section from the date of issue of that Certificate of } \\
\text { Completion, when the responsibility for the care of that Section of } \\
\text { the Works shall pass to the Owner. }\end{array}$ \\
\hline $\begin{array}{c}\text { (2000) } \\
\text { THSRC }\end{array}$ & $\begin{array}{l}\text { If, as a result of rectifying such loss or damage to the extent required } \\
\text { by the Owner, the Contractor incurs additional costs or is delayed in } \\
\text { its performance of the Works, the Contractor shall be entitled to } \\
\text { claim an increase in the Contract Price or an Extension of Time. }\end{array}$ \\
\hline \hline
\end{tabular}

Table 4 Contract comparison of Care of Works Risk allocate to the Contractor

\begin{tabular}{c|l}
\hline $\begin{array}{c}\text { Contract } \\
\text { Type }\end{array}$ & \multicolumn{1}{c}{ Care of Works } \\
\cline { 2 - 2 } $\begin{array}{c}\text { FIDIC } \\
\text { (1995) }\end{array}$ & $\begin{array}{l}\text { Risk allocate to Contractor } \\
\text { Works and Goods from the Commencement Date until the } \\
\text { Taking-Over Certificate for the Works. If any loss or damage } \\
\text { happens to the Works, Goods or Contractor's Documents during the } \\
\text { period when the Contractor is responsible for their care. }\end{array}$ \\
\hline $\begin{array}{c}\text { NEC/ECC } \\
\text { (1995) }\end{array}$ & $\begin{array}{l}81.1 \text { From the starting date until the defects certificate has been } \\
\text { issued the risks which are not carried by the employer are carried by } \\
\text { the contractor. }\end{array}$ \\
\hline $\begin{array}{c}\text { AIA/A201 } \\
\text { (1997) }\end{array}$ & $\begin{array}{l}\text { 32.1The Contractor shall be responsible for the care and custody of } \\
\text { the Facilities or any part thereof until the date of Completion of the } \\
\text { Facilities. }\end{array}$ \\
\hline $\begin{array}{c}\text { ENAA } \\
\text { THSRC } \\
\text { Construction } \\
\text { (2000) }\end{array}$ & $\begin{array}{l}\text { The Contractor shall take full responsibility for the care of the } \\
\text { Works and for materials, plant and equipment for incorporation } \\
\text { therein, from the Commencement Date until the date of issue of a } \\
\text { Certificate of Completion for the whole of the Works. }\end{array}$ \\
\hline $\begin{array}{c}\text { THSRC } \\
\text { Core System } \\
\text { (2000) }\end{array}$ & $\begin{array}{l}\text { The Contractor shall, unless otherwise expressly provided in the } \\
\text { Installation Contract, be responsible for the care of, and bear the } \\
\text { risk of loss of or damage to, each part of the Works from whatever } \\
\text { cause from the Commencement Date until the Taking-Over Date. }\end{array}$ \\
\hline \hline
\end{tabular}

4.1 Conditions of contract on Variation 
"Variation" clauses in the each international standard form were compared in Table 2.

\subsection{Conditions of contract on Care of Works}

"Care of Works" clauses in each international standard form were compared in Table 3 and 4. The risk allocation concerns with owner and contractor was divided into Table 3 and Table 4 individually.

4.3 Conditions of contract on Cooperation \& Coordination

"Cooperation \& Coordination" clauses in each international standard form were compared in Table 5.

By the comparison of above contract clauses, the result showed that the THSRP contracts can not be said real unfair or unreasonable. But actually when faced a lot of interface issues and uncertain factors between construction and core system contractors during the construction period at the jobsite, it is very difficult to have a consensus of the contract clauses and make an agreement.

Table 5 Contract comparison of Cooperation \& Coordination clauses

\begin{tabular}{|c|c|}
\hline $\begin{array}{c}\text { Contract } \\
\text { Type }\end{array}$ & Cooperation \& Coordination \\
\hline $\begin{array}{l}\text { FIDIC } \\
(1995)\end{array}$ & $\begin{array}{l}\text { The Contractor shall, as specified in the Contract or as instructed by } \\
\text { the Employer, allow appropriate opportunities for carrying out work } \\
\text { to:(a) the Employer's Personnel,(b) any other contractors employed } \\
\text { by the Employer, (c) the personnel of any legally constituted public } \\
\text { authorities, who may be employed in the execution on or near the } \\
\text { Site of any work not included in the Contract. }\end{array}$ \\
\hline $\begin{array}{c}\text { NEC/ECC } \\
(\mathbf{1 9 9 5 )}\end{array}$ & $\begin{array}{l}25.1 \text { The Contractor co-operates with others in obtaining and } \\
\text { providing information which they need in connection with the works. } \\
\text { He shares the Working Areas with others as stated in the Works } \\
\text { Information. }\end{array}$ \\
\hline $\begin{array}{c}\text { AIA/A201 } \\
\text { (1997) }\end{array}$ & $\begin{array}{l}\text { 6.1.3 The Owner shall provide for coordination of the activities of } \\
\text { the Owner's own forces and of each separate contractor with the } \\
\text { Work of the Contractor, who shall cooperate with them. }\end{array}$ \\
\hline $\begin{array}{l}\text { ENAA } \\
(1996)\end{array}$ & $\begin{array}{l}\text { The Contractor shall also arrange to perform its work so as to } \\
\text { minimise, to the extent possible, interference with the work of other } \\
\text { contractors. The Project Manager shall determine the resolution of } \\
\text { any difference or conflict that may arise between the Contractor and } \\
\text { other contractors and the workers of the Employer in regard to their } \\
\text { work. }\end{array}$ \\
\hline $\begin{array}{l}\text { THSRC } \\
\text { Construction } \\
\text { (2000) }\end{array}$ & $\begin{array}{l}\text { The Contractor's responsibilities with regard to interface } \\
\text { management and co-ordination with Interfacing Parties. Interface } \\
\text { and co-ordination of the Works will include the co-ordination of all } \\
\text { technical \& programming matters with the various Interfacing } \\
\text { Parties to achieve fully coordinated construction. }\end{array}$ \\
\hline $\begin{array}{c}\text { THSRC } \\
\text { Core System } \\
(2000) \\
\end{array}$ & ditto \\
\hline
\end{tabular}

\section{CASE STUDY AND ANALYSIS}

In this case study, three cases in THSRP were used to verify the interface conflicts between construction and core system contractors, due to these interface issues bring the risk allocation problems in THSRP.

\section{Case 1.The Core System Contractor is the Risk Trigger}

In the depot of THSRP, the circuit piping, sensor and some embedment of the foundation of "Ascending Machine Pit \& Turn Table of Train” must handover to the construction contractor to embed before concrete cast. But the original design is type-A machinery, due to the material of the design can not match of the specification. So design can not confirm. Therefore core system contractor changed the design a lot of times. Also the final design used the type-B machinery. So it affected the size, shape, dimensions, level and direction etc. of the foundation. This situation made construction contractor need to follow the variation to modify the foundation formwork, rebars, piping, embedment etc. Level of the foundation required high precision, so need to modify for it to match the requirements a lot of times.

Because of long time waiting the result of variation, the concrete can not be cast, and idling for going next step of the works. The modification of design increased the cost and made the schedule lost control.

This is the case of construction contractor face unexpected happenings and to suffer unknown risks due to the core system contractor's activities.

Case Analysis: this case showed the above risk categories, A07.Change or add in the plant \& equipment (including equipment, material, tests), A03. Change the level, location, \& size of the structure, B01. Design Drawing not so clearly, B02. Jobsite can not fellow the design and specification, which were triggered from the core system contractor.

\section{Case2. The construction contractor is the Risk Trigger}

The core system contractor need go into the building to install the piping of the signal and communication equipment in one station of THSRP. When they arrived and start to install, found the piping conflicted with the fire fighting system which already installed by construction contractor. It also didn't have enough space to install their own design to install the fire fighting system because of their own convenience. Therefore they informed the construction contactor to change it. Because of the long waiting time, four more months were spent to finish the work behind the original schedule. This is the case Core System Contractor face unexpected happenings and to suffer unknown risks due to the Construction contractor's activities.

Case Analysis: this case showed the above risk categories, B02.Jobsite can not fellow the design and specification, B03. Lack of the supervision and manage ability and B05. Delay in Instruction Variation which were triggered from Construction Contractor.

\section{Case3. The Owner is the Risk Trigger}

This case is the risk trigger of owner led to the construction and core system contractors bearing the risk. Because of the owner request the construction contractor to vary the earthing system of the raised floor in signal communication equipment room of the station. The original diameter of the earthing cable was $2 \mathrm{~mm}^{2}$ and change it into14 $\mathrm{mm}^{2}$.The reason of variation was original 
design can not match the safety regulation in law. So the owner instructed to vary it.

However the whole earthing system must redo. All original system must be taken out and wait the result of variation from owner. It also need inspect the new materials with owner, resend the working methods to verify and order new type of the earthing materials, and arrange to reinstall. The loss time for waiting and redoing was about one month. However the actually working time was around four days. So in this case not only loss the manpower, materials and time but also the whole schedule. Lead to the construction contractor can not go into install the all raised floor and also lead to the core system contractor can not go on to install the panel and the earth of panel. This case let the construction and core system contractor take the time and cost risk also can not estimate the finished time.

Case Analysis: this case showed the above risk categories, A02. Change the quality and characteristic in the contract, and B05.Delay in Instruction Variation which were triggered form Owner.

The project owner, construction and core system contractor may be one of the risk triggers in the interface risks. These cases only offer some scenario in the real project to explain actually no one is the winner. Therefore risk allocation must be paid more attention to analysis and arrange in the contract clauses for the engineering interfaces among owner, construction contractor and core system contractor.

\section{CONCLUSIONS}

This study tried to identify risk factors of interface between construction and core system contractors by comparing the contract conditions in the FIDIC, AIA, NEC, and ENAA, and from the brainstorming and interview with practitioners and senior engineers, seven categories of interface risks was classified as (A) Variation; (B) Care of works; (C) Force Majeure; (D) Cooperation \& Coordination; (E) Chang in Laws; (F) Contractor's Liability; (G) Suspension and Termination.

To identify significant risks in interfaces between construction and core system contractors in THSRP, a questionnaire survey was undertaken. The top three risk categories of "Variation Risk", "Care of Works Risk" and "Cooperation \& Coordination Risk" were deemed as the risk triggers by owner, construction contractor and core system contractor.

The results of contract comparison and investigation showed that the THSRP contracts can not be said real unfair or unreasonable. But, there is not any contract relationship between construction and Core System Contract; even the owner put the "Cooperation \& Coordination" clauses in the each contract. Both of parties must follow to cooperate each other and take some risk from the working interface. But actually when faced a lot of interface issues and uncertain factors between construction and core system contractors during the construction period at the jobsite, it is very difficult to have a consensus of the contract clauses and make an agreement.

The project owner, construction contractor and core system contractor may be one of the risk triggers in the interface risks. Three real cases in THSRP were used to explain actually no one is the winner when interface risk happened. Therefore risk allocation must be paid more attention to analysis and arrange in the contract clauses for the engineering interfaces among owner, construction contractor and core system contractor.

This study suggests that during contract making in the future, may add one clause about the risk principles to stipulate the one who request or lead to variation and cause risk condition must take the risk from it. Otherwise, all parties may agree to share the responsibilities and risks.

The results of this study can feedback to the infrastructure projects as a reference for each party in making an acceptable contract, let the contract be fair and reasonable so that the risks and disputes can be reduced, then the project can be processed smoothly.

\section{REFERENCES}

[1]Ming-Teh Wang, and Hui-Yu Chou(2003). "Risk Allocation and Risk Handling of Highway Projects in Taiwan”, Journal of Management in Engineering, ASCE, pp60-68

[2]Mei-Chun Ku,(2004),"Risk Allocation and Common Disputes of Construction Contracts", Institute of Technology Law. NCTU.

Appendix

Contracts referred to in the text are:

AIA: The American Institute of Architects, AIA Document A201-1997, General Conditions of Contract for Construction (1997)

ENAA: Engineering Advancement Association of Japan, ENAA Model Form International Contract for Power Plant Construction (Turnkey Lumpsum Basis), General Conditions (1996).

FIDIC: International Federation of Consulting Engineers, Guide to the use of FIDIC Conditions of Contract for Design-Build and Turnkey ( $1^{\text {st }}$ edition. 1995)

NEC/ECC: The Institution of Civil Engineers, The NEC Engineering and Construction Contract ( $2^{\text {nd }}$ edition.1995) 